\title{
BIOINFORMATION

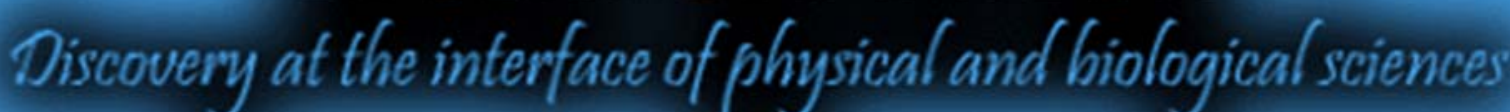

\section{Computer aided screening and evaluation of herbal therapeutics against MRSA infections}

\author{
Sinosh Skariyachan ${ }^{1}{ }^{*}$, Rao Shruti Krishnan1, Snehapriya Bangalore Siddapa1, Chithra Salian', \\ Prerana Bora1, Denoj Sebastian²
}

1Department of Biotechnology, Dayananda Sagar College of Engineering, Bangalore, India; 2Department of Microbiology, University of Calicut, Kerala, India; Sinosh Skariyachan - Email: sinoshskariya@gmail.com; Phone: +91-9739654015; *Corresponding author

Received October 10, 2011; Accepted October 11, 2011; Published October 31, 2011

\begin{abstract}
:
Methicillin resistant Staphylococcus aureus (MRSA), a pathogenic bacterium that causes life threatening outbreaks such as community-onset and nosocomial infections has emerged as 'superbug'. The organism developed resistance to all classes of antibiotics including the best known Vancomycin (VRSA). Hence, there is a need to develop new therapeutic agents. This study mainly evaluates the potential use of botanicals against MRSA infections. Computer aided design is an initial platform to screen novel inhibitors and the data finds applications in drug development. The drug-likeness and efficiency of various herbal compounds were screened by ADMET and docking studies. The virulent factor of most of the MRSA associated infections are Penicillin Binding Protein 2A (PBP2A) and Panton-Valentine Leukocidin (PVL). Hence, native structures of these proteins (PDB: 1VQQ and 1T5R) were used as the drug targets. The docking studies revealed that the active component of Aloe vera, $\beta$-sitosterol (3S, 8S, 9S, 10R, 13R, 14S, 17R) -17- [(2R, 5R)-5-ethyl-6-methylheptan-2-yl] -10, 13-dimethyl 2, 3, 4, 7, 8, 9, 11, 12, 14, 15, 16, 17dodecahydro-1H-cyclopenta [a] phenanthren-3-ol) showed best binding energies of $-7.40 \mathrm{kcal} / \mathrm{mol}$ and $-6.34 \mathrm{kcal} / \mathrm{mol}$ for PBP2A and PVL toxin, respectively. Similarly, Meliantriol (1S-1-[ (2R, 3R, 5R)-5-hydroxy-3-[(3S, 5R, 9R, 10R, 13S, 14S, 17S)-3-hydroxy 4, 4, 10, 13, 14-pentamethyl-2, 3, 5, 6, 9, 11, 12, 15, 16, 17-decahydro-1H-cyclopenta[a] phenanthren-17-yl] oxolan-2-yl] -2methylpropane-1, 2 diol), active compound in Azadirachta indica (Neem) showed the binding energies of $-6.02 \mathrm{kcal} / \mathrm{mol}$ for PBP2A and -8.94 for PVL toxin. Similar studies were conducted with selected herbal compound based on pharmacokinetic properties. All in silico data tested in vitro concluded that herbal extracts of Aloe-vera, Neem, Guava (Psidium guajava), Pomegranate (Punica granatum) and tea (Camellia sinensis) can be used as therapeutics against MRSA infections.
\end{abstract}

Key words: Superbug, MRSA, PBP2A, PVL toxin, docking, $\beta$-sitosterol, Meliantriol

\section{Background:}

Methicillin resistant Staphylococcus aureus (MRSA) is a notorious pathogenic bacterium causing many infections and the disease control has become a serious issue worldwide [1]. The high outbreak of MRSA was observed in closed communities such as schools, prisons and sports teams and the disease has mainly transmitted from fomite to person and from person to person and so on [2]. The pathogenecity of the bacteria includes skin and soft tissue infections (SSTI), bone, joint and implant infections, pneumonia, septicemia and various toxicoses such as toxic shock syndrome, bloodstream infections, osteomyelitis, septic arthritis, and device-related infections, necrotizing fasciitis and purpura fulminans and abscesses [3]. Recent reports indicated the emergence of multidrug resistant Staphylococci against all classes of $\beta$-lactam antibiotics. The antibiotic resistance is mainly due to the expression of PC1 $\beta$ lactamase and the acquisition of mecA gene encoding a penicillin-binding protein, PBP2A [4]. The bacteria initially penetrate the host's immune system via epidermal and mucosal epithelia and the antimicrobial peptides play necessary role in 
the host's innate immune defense against the initial colonization of bacteria [5]. It has been studied that many strains of MRSA contain genes that encode the toxin called Panton Valentine Leukocidin (PVL), bi-component leukocidal toxins (synergohymenotropic toxins) consists of $\mathrm{F}$ and $\mathrm{S}$ components. PVL is encoded by the lukPVoperon encoding the LukF-PV and LukS-PV components (cytotoxins) that lyse leukocyte. Hence, PVL positive Staphylococcal infections exist as life threatening infections of soft tissues and bones [6].

Recent studies revealed that strains of MRSA developed resistance to conventional antibiotics and emerged as multidrug resistant superbugs. Hence, there is a significant demand of finding better therapeutic agents. The active substances present in many medicinal plants could be used as therapeutic alternatives for MRSA infection [7]. Computer aided method is a preliminary approach to screening novel therapeutic agents and the discipline is an emerging strategy as it reduces many complexities of drug discovery process. The screening of lead molecule with good pharmacological properties and drug likeness is a tedious task in drug development process. Computer aided method is an easy platform to search such kinds of biologically active compounds with favorable ADMET (Absorption, Distribution, Metabolism, Excretion and Toxicity) and drug-likeness properties [8]. The study of receptor-ligand interaction is a fundamental concept of rational drug design and the prediction of such interactions by computational docking has increasing importance in the field of structure based drug discovery [9].

The study mainly focused to screen potential herbal inhibitors against the drug targets of MRSA by computer based ADMET and docking studies. The data obtained from in silico studies were later used for in vitro studies. The study also provides a comparative account of the efficiency of herbal compounds to that of known antibiotics.

\section{Methodology: \\ Identification of potential ligands}

Since MRSA has emerged as a multidrug resistant organism the design of alternative therapies are very crucial to treat MRSA outbreaks. There are reports that many herbal based compounds have high medicinal values against many pathogens. Hence, an initial survey of 74 compounds from 13 different medicinal plants was carried out by extensive literature studies. It is possible to find out the druggish properties of herbal compounds by computer aided screening and the data will be useful to screen best lead molecules. The 3D structures of all plant based ligands are available in drug data base and the structures were retrieved from PubChem [10], KEGG [11] and Chemspider [12].

\section{ADMET studies and screening of ligands}

The ligands with good pharmacological and druggish properties are very crucial for structure based drug discovery. The absorption, distribution, metabolism, excretion and toxicity (ADMET) are the most important part of pharmacological studies of lead molecules and these can be predicted by computational biology tools. Hence, all 74 ligands identified were tested for their drug-likeliness, ADME profile and toxicity analysis by Pre-ADMET. The ADME includes the extent and rate of absorption, distribution, metabolism and excretion. Absorption checks how the substance is entering to the blood circulation, distribution explains how substances are disseminating throughout the fluids and tissues of the body, metabolism is the irreversible transformation of parent compounds into daughter metabolites and excretion explains how the substances are excreted from the body after metabolism. Pre-ADMET uses Caco2-cell (heterogeneous human epithelial colorectal adenocarcinoma cell lines) and MDCK (Madin-Darby Canine Kidney) cell models for oral drug absorption prediction and skin permeability, and human intestinal absorption model for oral and trans-dermal drug absorption prediction. Similarly, the programme uses BBB (blood brain barrier) penetration and plasma protein binding models to predict the distribution. Pre-ADMET predicts toxicity based on the mutagenicity of AMES parameters and rodent carcinogenicity assays of rat and mouse [13].

\section{Selection of target proteins and molecular docking}

The receptor and ligand interaction is the key mechanism of computer aided drug design. Previous studies reported that Penicillin Binding Protein 2A (PBP2A) and Panton-Valentine Leukocidin (PVL) are the major virulent factors of MRSA infections $[\mathbf{1 4}, \mathbf{1 5}]$. Hence, the native structures of the proteins are used as drug targets. The crystal structures of PBP2A (1VQQ) and PVL toxin (1T5R) were retrieved from Protein Data Bank and the coordinate files were used for the study. The selected herbal compounds were docked with target proteins by AutoDock. The program uses a Monte Carlo simulated annealing for configurational exploration using grid based molecular affinity potentials and provides bioactive conformation by energy minimization [16].

\section{In vitro studies}

The data generated by computer aided studies should be tested experimentally for further confirmation. Based on the pharmacological properties studied by ADMET \& docking studies, five botanicals were identified for in vitro testing. The botanicals used in the study are Azadirachta indica [17], Aloe vera [18], Camellia sinensis [19], Punica granatum [20] and Psidium guajava [21]. The herbals were collected from Horticulture Centre-Hulimavu, Bangalore. The leaf extracts were prepared by standard solvent extraction method and the antimicrobial activity of each extract was tested in different concentrations. The pure culture of MRSA was swabbed on Muller Hinton agar plates which have many wells. The extracts were added in different concentration to each well (well diffusion method) and the plates were incubated at $37^{\circ} \mathrm{C}$ for 24 hours. The antimicrobial activity was determined by measuring the zone of inhibition. The efficiency of herbal extracts was also compared with known antibiotics. The antibiotic susceptibility patterns were carried out by disc diffusion method. The sensitivity patterns of each antibiotic were confirmed by measuring the zone of inhibition around the disc and compared with standard antibiotic susceptibility chart.

Discussion:

The solution for MRSA associated outbreaks are critical problem because the organism recently emerged as VRSA. Hence, the discovery of an alternative treatment has profound scope and significance. Drug discovery process is time consuming and multistep process which includes many preclinical and clinical trials. One of the major reasons for drug failures is the poor drug-likeness and pharmacokinetic properties of lead compounds. Computer aided method is a rapid and significant screening approach because it selects the lead molecules with good pharmacological and druggish properties. We have selected 74 active compounds from herbal origin such as leaf extracts of Azadirachta indica (Neem), Psidium 
guajava (Guavas), Aloe vera, Ocimum tenuiflorum (Tulsi), Curcuma longa (Turmeric), Allium satioum (Garlic), Punica granatum (Pomegranate), Eucalyptus, Camellia sinensis (Tea) and the oil of Syzygium aromaticum (Clove). The 3D structures of the ligands were retrieved from drug databases and most of lead molecules qualified the properties of drugs. However, few ligands were found to be better as per Lipinski's rule of 5, CMC-like rule and MDDR-like rule (Table 1, see supplementary material).

Another important concern in drug discovery is the pharmacokinetics properties. The ADME profiles of selected drug candidates are shown in Table 2 (see supplementary material). In silico toxicity prediction is the final step of pharmacokinetic screening of lead molecules and 30\% of drug failures are due to toxicity issues. In this study, we have found that the predicted toxicities of many herbal compounds were suitable for further studies. Meliantriol from Azadirachta indica, $\beta$-sitosterol from Alo vera, ursolic acid and lupeol from Ocimum tenuiflorum, brevifolin and ellagic acid from Punica granatum, corilagin from Camellia sinensis, and many more showed better pharmacokinetic and drug-likeness properties (Table 3, see supplementary material). Hence, these lead molecules were identified as the best ligands for docking studies. All these herbal extracts were reported to have high medicinal potential against many pathogenic bacteria and we have tested efficiency of the same against MRSA by computer aided approach and in vitro studies.

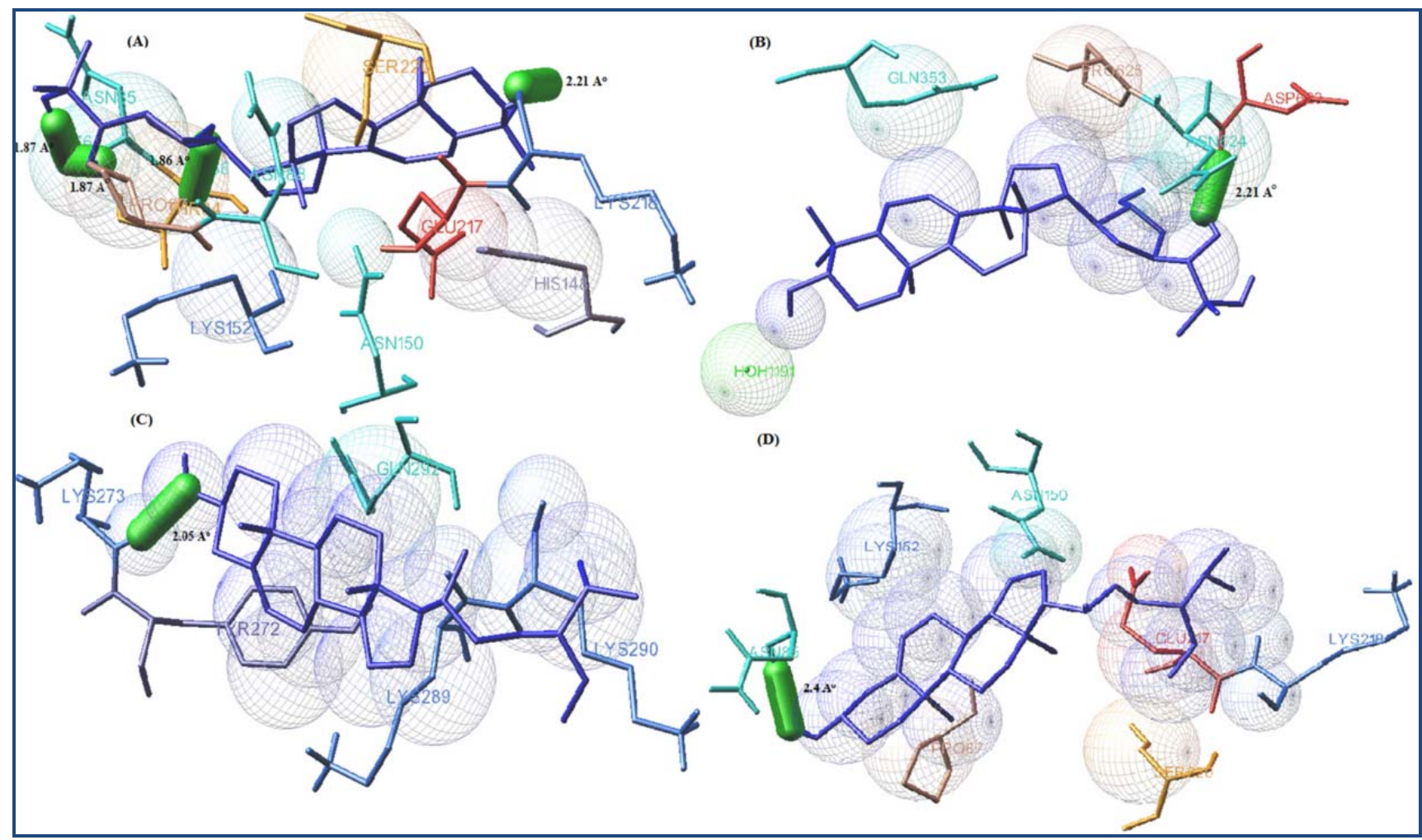

Figure 1: The interaction of Meliantriol and $\beta$-Sitosterol against MRSA drug targets- Penicillin Binding Protein 2A (PBP2A) and Panton-Valentine Leukocidin (PVL) generated by computer aided docking. Neem active compound Melantriol interacts with PVL toxin by four hydrogen bonds (represented as green coloured sticks) and the interacting residues are LYS218 of chain A, THR 84, ASN 85 and ASN 86 of chain E. The lengths of the hydrogen bonds are $2.1 \AA, 1.86 \AA$, $1.8 \AA$ and $1.87 \AA$ respectively (Figure A). Melantriol interacted with PBP2A by ASP 624 of Chain A and the length of the bond formed was $2.21 \AA$ (Figure B). The ligand effectively binds with both PBP2A and PVL toxin with minimum binding energies of $-6.02 \mathrm{kcal} / \mathrm{mol} \mathrm{and}-8.94 \mathrm{kcal} / \mathrm{mol}$ respectively. Figure $\mathbf{C}$ and $\mathbf{D}$ showed the inhibitory activity of Aloe vera active compound $\beta$-sitosterol against both the targets. The ligand interacted to PBP2A by LYS273 (Chain A) with hydrogen bond of length $2.05 \AA$ (Figure C). Similarly, $\beta$-sitosterol interacted with PVL toxin by ASN 85 of Chain A with one hydrogen bond of $2.4 \AA$ (Figure D). $\beta$-sitosterol is also identified as best lead molecule against MRSA targets with minimum binding energy of $-7.40 \mathrm{kcal} / \mathrm{mol}$ for PBP2A and $-6.34 \mathrm{kcal} / \mathrm{mol}$ for PVL toxin. The docking studies revealed that herbal compounds have good pharmacological activities against MRSA targets.

The key proteins involved in MRSA infections are PBP2A and PVL toxins. Hence, these proteins have been selected as probable drug targets. The crystal structure of Penicillin Binding Protein 2A (PDBID: 1VQQ) was retrieved from the PDB. The protein consists of two chains and three penicillin binding protein domains. Chain A is the key domain consists of 646 amino acids and constitutes 33\% helices (31 helices; 214 residues) and $26 \%$ beta sheet (34 strands; 169 residues) which are important for the functional activity. The crystal structure of Panton-Valentine Leucocidin (PDBID: 1T5R) was also retrieved from PDB and it has 8 chains. All chains have 284 amino acid residues and constitute 3\% helices (3 helices; 11 residues) and $59 \%$ beta sheet (22 strands; 168 residues). The interactions between selected inhibitors and target proteins were studied by docking simulations. Among antibiotics, Vancomycin, best drug currently available against MRSA, showed the best binding energy value of $-8.91 \mathrm{kcal} / \mathrm{mol}$. However, recent reports indicate that the organism developed resistance against Vancomycin and emerged as Vancomycin resistant Staphlococcus areus (VRSA). The binding efficiencies of herbal 
active compounds also tested against the target proteins by molecular docking. The docking scores and binding energies of all selected ligands with both the targets were shown in Table 4 (see supplementary material). As the best, Meliantriol, active inhibitor present in Neem, showed binding energies of -6.02 $\mathrm{kcal} / \mathrm{mol}$ with PBP2A and $-8.94 \mathrm{kcal} / \mathrm{mol}$ with PVL toxin. Similarly, $\beta$-sitosterol, an antimicrobial agent present in medicinal aloe, showed binding energies of $-7.40 \mathrm{kcal} / \mathrm{mol}$ and $-6.34 \mathrm{kcal} / \mathrm{mol}$ for PBP2A and PVL toxin respectively (Figure 1). The docking studies reveled that herbal compounds are better inhibitors than chemical drugs; Meliantriol and similar compounds are the potential lead molecules than Vancomycin. As per computer aided studies plant derived inhibitors have high therapeutic value and it should be evaluated through in vitro studies.

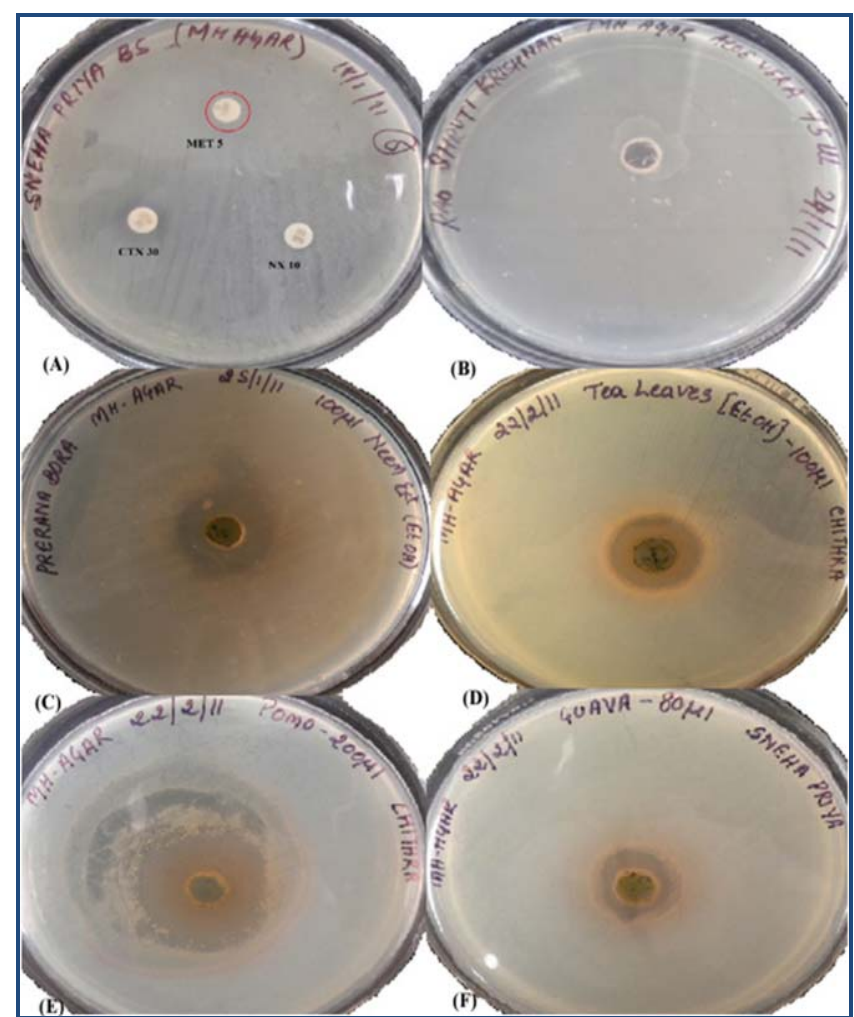

Figure 2: The therapeutic potential of selected herbal based compounds against MRSA confirmed by in vitro studies. The antibiotic susceptibility pattern was identified by Kirby-Bauer disc diffusion method. The resistance pattern of Staphylococcus areus against Methicillin is encircled and which was characterized by lack of zone of inhibition implies resistance. Similarly the organism shows resistance against Cefatoxime (30 $\mathrm{mcg} /$ disc), Norflaxacin (10 mcg/disc) and other antibiotics (Table 5, see supplementary material). Hence, the treatment with antibiotics are challenging in future. Figure B to F indicate the efficiency of herbal compounds against MRSA. As confirmed by computer aided screening neem active compound melantriol has significant antimicrobial activity against MRSA, represented by the zone of inhibition (C) around the well (well diffusion method). Figure $B$ shows that the inhibitory activity of $\beta$-sitosterol (Aloe vera active compound) characterized by zone of clearance around the well, which was selected from docking studies. As screened by the computer aided approach, the active compound present in tea leaf $(\mathrm{D})$, pomogranate $(\mathrm{E})$, and guava (F) showed good inhibitory properties against MRSA.
Thus, the study clearly indicates that herbal compounds have good therapeutic value against MRSA than antibiotics.

Since the data generated by computer aided method has just a hypothetical solution it should be tested in vitro also. We have studied and compared the efficiency of antibiotics and selected herbal extracts (The active compounds of those extracts found to be effective by docking studies) against pure culture of MRSA. The method employed was disc diffusion and well diffusion techniques. Our study revealed that the organism resistant to wide range of antibiotics such as Moxifloxacin, Cefatoxime, Rifampicin, Oxacillin, Co-Trimoxazole, Chloramphenicol Ciprofloxacin, Ceftazidime, Nalidixic acid, Tetracycline, Streptomycin, Erythromycin, Ampicillin, Norfloxacin and Methicillin. The organism is susceptible to only few antibiotics, Vancomycin is the best one. Moreover, recent studies on Vancomycin resistant Staphylococcus areus (VRSA) indicated that antibiotic treatments are challenging and pointing out 'the end of antibiotic era' is very near in future. The susceptibility pattern of various antibiotics against MRSA is shown in Table 5 (see supplementary material). Nonetheless, interestingly, as confirmed by the computer aided approach, the leaf extracts of Neem, Tea, Guava and Pomegranate showed better antimicrobial properties at a concentration of $100 \mu \mathrm{l}, 100$ $\mu \mathrm{l}, 80 \mu \mathrm{l}$ and $200 \mu \mathrm{l}$ respectively, which implies the potential of herbal extract against MRSA (Figure 2). The computer aided method is useful to screen best ligands from wide range of compounds which will reduce the complexities of drug discovery process. Subsequently, the study needs more clinical testing using laboratory animals and further in vivo studies should be conducted. The study would provide all initial inputs to design novel therapeutics against MRSA.

\section{Conclusion:}

Present studies revealed that the mortality rate of MRSA infection is very high and the organism is resistant to Vancomycin (VRSA), the best chemotherapeutic agent available against MRSA. This study concluded that computer aided screening is an effective alternative for identification of novel remedies when all antibiotics seems to have failed. Several natural herbal compounds are screened and their effectiveness against MRSA is compared with known antibiotics. Computer aided ADME and toxicity prediction favored to screen best ligands with good pharmacological activities. It was found that herbal compounds such as Melantriol, $\beta$ - Sitosterol and similar compounds have good inhibitory activity against Penicillin Binding Protein 2A and Panton-Valentine Leukocidin toxin of MRSA, key virulent factors of MRSA infections. The in silico data have been tested in vitro also, as suggested by computer aided method, herbal extracts of neem, medicinal aloe, tea, pomegranate and guava were identified as potential therapeutics against MRSA. The study concluded that, though the organism emerged as a multidrug resistant "superbug" there is high scope and application of herbal remedies towards MRSA infections.

\section{Acknowledgement:}

The authors thankfully acknowledge the R \& D Centre of Life Sciences and Engineering, Dayananda Sagar Institutions for providing all necessary facilities and also grateful to Dr. P.S Rao, Vice President (R \& D), Life Sciences and Engineering and Dr. G S Jagannatha Rao, Senior Professor and Head, Department of Biotechnology, Dayananda Sagar College of Engineering for their constant support and encouragement throughout the study. 
References:

[1] Kuehnert MJ et al. Emerg Infect Dis. 2005 11: 868 [PMID: 15963281]

[2] David MZ et al. PLoS One. 2011 6: e18217 [PMID: 21533238]

[3] Monecke S et al. PLoS One. 2011 6: e17936 [PMID: 21494333]

[4] Llarrull LI et al. Antimicrob Agents Chemother. 2009 53: 4051 [PMID: 19470504]

[5] Ouhara K et al. J Antimicrob Chemother. 2008 61: 1266 [PMID: 18367458]

[6] Diep BA \& Otto M. Trends Microbiol. 2008 16: 361 [PMID: 18585915]

[7] Chomnawang MT et al. Fitoterapia 2009 80:102 [PMID: 19022354]

[8] Khanna V \& Ranganathan S. BMC Bioinformatics. 2009 10: S10 [PMID: 19958509]

[9] Lyskov S \& Gray JJ. Nucleic Acids Res. 2008 36:W233 [PMID: 18442991]

[10] Wang Y et al. Nucleic Acids Res. 2010 38: D255 [PMID: 19933261]
[11] Kanehisa M et al. Nucleic Acids Res. 2010 38: D355 [PMID: 19880382]

[12] Anthony J W et al. J Cheminform. 2010 2: O16 [PMCID: PMC2867124]

[13] Seal A et al. Bioinformation 2011 5: 430 [PMID: 21423889]

[14] Lim D \& Strynadka NC. Nat Struct Biol. 2002 9: 870 [PMID: 12389036]

[15] Guillet V et al. J Biol Chem. 2004 279: 41028 [PMID: 15262988]

[16] Morris GM et al. J Comput Aided Mol Des. 1996 10: 293 [PMID: 8877701]

[17] Kareru PG et al. Afr J Tradit Complement Altern Med. 2010 7: 214 [PMCID: PMC3025622]

[18] Habeeb F et al. Methods 2007 42: 315 [PMID: 17560318]

[19] Cho YS et al. Curr Microbiol. 2008 57: 542 [PMID: 18781360]

[20] Aqil F et al. J Basic Microbiol. 2005 45: 106 [PMID: 15812867]

[21] Metwally AM et al. Pharmacogn Mag. 2010 6: 212 [PMID: 20931082]

Edited by P Kangueane

Citation: Skariyachan et al. Bioinformation 7(5): 222-233 (2011)

License statement: This is an open-access article, which permits unrestricted use, distribution, and reproduction in any medium, for non-commercial purposes, provided the original author and source are credited. 


\section{Supplementary material:}

Table 1: Drug-likeliness prediction of selected herbal compounds using Pre-ADMET tool. The main rules used to test the drug likeliness were Lipinski's Rule, Lead like Rule, CMC-like rule, MDDR-like rule and WDI-like rule. Melantriol and $\beta$-sitosterol have qualified most of the rules and these compounds have selected for further studies.

\begin{tabular}{|c|c|c|c|c|c|c|}
\hline $\begin{array}{l}\text { Active Component in plant } \\
\text { extract }\end{array}$ & Source & $\begin{array}{l}\text { Lipinski's } \\
\text { Rule }\end{array}$ & $\begin{array}{l}\text { Lead like } \\
\text { Rule }\end{array}$ & $\begin{array}{l}\text { CMC-like } \\
\text { rule }\end{array}$ & $\begin{array}{l}\text { MDDR-like } \\
\text { rule }\end{array}$ & WDI-like rule \\
\hline Nimbin & Neem & Suitable & Violated & $\begin{array}{l}\text { Not } \\
\text { qualified }\end{array}$ & Midstructure & $\begin{array}{l}\text { Out of } 90 \% \\
\text { cutoff }\end{array}$ \\
\hline Quercetin & Neem & Suitable & Suitable & Qualified & Midstructure & In $90 \%$ cutoff \\
\hline Meliantriol & Neem & Suitable & Suitable & Qualified & Midstructure & In $90 \%$ cutoff \\
\hline Aloin & Aloe vera & Suitable & Violated & $\begin{array}{l}\text { Not } \\
\text { qualified }\end{array}$ & Midstructure & $\begin{array}{l}\text { Out of } 90 \% \\
\text { cutoff }\end{array}$ \\
\hline Emodin & Aloe vera & Suitable & Suitable & Qualified & Midstructure & In $90 \%$ cutoff \\
\hline Salicyclic acid & Aloe vera & Suitable & Violated & $\begin{array}{l}\text { Not } \\
\text { qualified }\end{array}$ & Non-druglike & $\begin{array}{l}\text { Out of } 90 \% \\
\text { cutoff }\end{array}$ \\
\hline Cholestrol & Aloe vera & Suitable & Violated & $\begin{array}{l}\text { Not } \\
\text { qualified }\end{array}$ & Midstructure & $\begin{array}{l}\text { Out of } 90 \% \\
\text { cutoff }\end{array}$ \\
\hline Campesterol & Aloe vera & Suitable & Violated & $\begin{array}{l}\text { Not } \\
\text { qualified }\end{array}$ & Midstructure & $\begin{array}{l}\text { Out of } 90 \% \\
\text { cutoff }\end{array}$ \\
\hline Lupeol & Aloe vera & Suitable & Violated & $\begin{array}{l}\text { Not } \\
\text { qualified }\end{array}$ & Midstructure & $\begin{array}{l}\text { Out of } 90 \% \\
\text { cutoff }\end{array}$ \\
\hline$\beta$-sitosterol & Aloe vera & Suitable & Suitable & Qualified & Midstructure & In $90 \%$ cutoff \\
\hline Oleanolic acid & Tulsi & Suitable & Violated & $\begin{array}{l}\text { Not } \\
\text { qualified }\end{array}$ & Midstructure & $\begin{array}{l}\text { Out of } 90 \% \\
\text { cutoff }\end{array}$ \\
\hline Ursolic acid & Tulsi & Suitable & Violated & $\begin{array}{l}\text { Not } \\
\text { qualified }\end{array}$ & Midstructure & $\begin{array}{l}\text { Out of } 90 \% \\
\text { cutoff }\end{array}$ \\
\hline Rosmarinic acid & Tulsi & Suitable & Violated & Qualified & Midstructure & In $90 \%$ cutoff \\
\hline Eugenol & Tulsi & Suitable & Suitable & Qualified & Midstructure & $\begin{array}{l}\text { Out of } 90 \% \\
\text { cutoff }\end{array}$ \\
\hline Carvacrol & Tulsi & Suitable & Violated & $\begin{array}{l}\text { Not } \\
\text { qualified }\end{array}$ & Midstructure & $\begin{array}{l}\text { Out of } 90 \% \\
\text { cutoff }\end{array}$ \\
\hline Linalool & Tulsi & Suitable & Suitable & $\begin{array}{l}\text { Not } \\
\text { qualified }\end{array}$ & Midstructure & $\begin{array}{l}\text { Out of } 90 \% \\
\text { cutoff }\end{array}$ \\
\hline Beta-caryophyllene & Tulsi & Suitable & Violated & Qualified & Midstructure & In $90 \%$ cutoff \\
\hline Methyl cinnamate & Tulsi & Suitable & Suitable & Qualified & Midstructure & In $90 \%$ cutoff \\
\hline Apigenin & Tulsi & Suitable & Suitable & Qualified & Midstructure & In $90 \%$ cutoff \\
\hline Luteolin & Tulsi & Suitable & Suitable & Qualified & Midstructure & In $90 \%$ cutoff \\
\hline curcumin & Turmeric & Suitable & Violated & $\begin{array}{l}\text { Not } \\
\text { qualified }\end{array}$ & Midstructure & $\begin{array}{l}\text { out of } 90 \% \\
\text { cutoff }\end{array}$ \\
\hline Demethoxy curcumin & Turmeric & Suitable & Violated & Qualified & Midstructure & $\begin{array}{l}\text { Out of } 90 \% \\
\text { cutoff }\end{array}$ \\
\hline Tumerone & Turmeric & Suitable & Violated & Qualified & Midstructure & In $90 \%$ cutoff \\
\hline Diaryl heptanoid & Turmeric & Violated & Violated & $\begin{array}{l}\text { Not } \\
\text { qualified }\end{array}$ & Midstructure & $\begin{array}{l}\text { Out of } 90 \% \\
\text { cutoff }\end{array}$ \\
\hline Allicin & Garlic & Suitable & Suitable & $\begin{array}{l}\text { Not } \\
\text { qualified }\end{array}$ & Midstructure & $\begin{array}{l}\text { Out of } 90 \% \\
\text { cutoff }\end{array}$ \\
\hline Diallyl sulphide & Garlic & Suitable & Suitable & $\begin{array}{l}\text { Not } \\
\text { qualified }\end{array}$ & Non-druglike & In $90 \%$ cutoff \\
\hline Diallyl disulphide & Garlic & Suitable & Suitable & $\begin{array}{l}\text { Not } \\
\text { qualified }\end{array}$ & Non-druglike & In $90 \%$ cutoff \\
\hline Brevifolin & Pomogranate & Suitable & Suitable & Qualified & Midstructure & $\begin{array}{l}\text { Out of } 90 \% \\
\text { cutoff }\end{array}$ \\
\hline Ellagic acid & Pomogranate & Suitable & Suitable & $\begin{array}{l}\text { Not } \\
\text { qualified }\end{array}$ & Non-druglike & In $90 \%$ cutoff \\
\hline Gallic acid & Pomogranate & Suitable & Violated & $\begin{array}{l}\text { Not } \\
\text { qualified }\end{array}$ & Midstructure & $\begin{array}{l}\text { Out of } 90 \% \\
\text { cutoff }\end{array}$ \\
\hline Epigallacatechin gallate & Tea & Violated & Violated & Qualified & Midstructure & $\begin{array}{l}\text { Out of } 90 \% \\
\text { cutoff }\end{array}$ \\
\hline Corilagin & Tea & Violated & Violated & $\begin{array}{l}\text { Not } \\
\text { qualified }\end{array}$ & Midstructure & $\begin{array}{l}\text { Out of } 90 \% \\
\text { cutoff }\end{array}$ \\
\hline Thymol & Clove & Suitable & Violated & $\begin{array}{l}\text { Not } \\
\text { qualified }\end{array}$ & Midstructure & $\begin{array}{l}\text { Out of } 90 \% \\
\text { cutoff }\end{array}$ \\
\hline Alpha-pinene & Eucalyptus & Suitable & Suitable & $\begin{array}{l}\text { Not } \\
\text { qualified }\end{array}$ & Midstructure & In $90 \%$ cutoff \\
\hline Benzyl benzoate & Eucalyptus & Suitable & Violated & Qualified & Midstructure & In $90 \%$ cutoff \\
\hline
\end{tabular}




\begin{tabular}{|c|c|c|c|c|c|c|}
\hline Geranial & Eucalyptus & Suitable & Violated & $\begin{array}{l}\text { Not } \\
\text { qualified }\end{array}$ & Midstructure & $\begin{array}{l}\text { Out of } 90 \% \\
\text { cutoff }\end{array}$ \\
\hline Limonene & Eucalyptus & Suitable & Violated & $\begin{array}{l}\text { Not } \\
\text { qualified }\end{array}$ & Midstructure & In $90 \%$ cutoff \\
\hline Ethyl cinnamate & Eucalyptus & Suitable & Suitable & Qualified & Midstructure & In $90 \%$ cutoff \\
\hline Terpinen & Eucalyptus & Suitable & Suitable & $\begin{array}{l}\text { Not } \\
\text { qualified }\end{array}$ & Midstructure & In $90 \%$ cutoff \\
\hline Thujene & Eucalyptus & Suitable & Suitable & $\begin{array}{l}\text { Not } \\
\text { qualified }\end{array}$ & Midstructure & In $90 \%$ cutoff \\
\hline Cinnamaldehyde & Cinnamon & Suitable & Suitable & $\begin{array}{l}\text { Not } \\
\text { qualified }\end{array}$ & Midstructure & In $90 \%$ cutoff \\
\hline Cinnamyl alcohol & Cinnamon & Suitable & Suitable & $\begin{array}{l}\text { Not } \\
\text { qualified }\end{array}$ & Midstructure & In $90 \%$ cutoff \\
\hline Cinnamyl acetate & Cinnamon & Suitable & Suitable & Qualified & Midstructure & In $90 \%$ cutoff \\
\hline Ferulic acid & Guava & Suitable & Violated & Qualified & Midstructure & $\begin{array}{l}\text { Out of } 90 \% \\
\text { cutoff }\end{array}$ \\
\hline Ascorbic acid & Guava & Suitable & Violated & $\begin{array}{l}\text { Not } \\
\text { qualified }\end{array}$ & Midstructure & In $90 \%$ cutoff \\
\hline Gallic acid & Guava & Suitable & Violated & $\begin{array}{l}\text { Not } \\
\text { qualified }\end{array}$ & Midstructure & $\begin{array}{l}\text { Out of } 90 \% \\
\text { cutoff }\end{array}$ \\
\hline Casuarinin & Guava & Violated & Violated & $\begin{array}{l}\text { Not } \\
\text { qualified }\end{array}$ & Midstructure & $\begin{array}{l}\text { Out of } 90 \% \\
\text { cutoff }\end{array}$ \\
\hline Cyanidin & Guava & Violated & Violated & $\begin{array}{l}\text { Not } \\
\text { qualified }\end{array}$ & Midstructure & $\begin{array}{l}\text { Out of } 90 \% \\
\text { cutoff }\end{array}$ \\
\hline Geraniol & Lemon Grass & Suitable & Violated & $\begin{array}{l}\text { Not } \\
\text { qualified }\end{array}$ & Midstructure & $\begin{array}{l}\text { Out of } 90 \% \\
\text { cutoff }\end{array}$ \\
\hline Citral & Lemon Grass & Suitable & Violated & $\begin{array}{l}\text { Not } \\
\text { qualified }\end{array}$ & Midstructure & $\begin{array}{l}\text { Out of } 90 \% \\
\text { cutoff }\end{array}$ \\
\hline Geranic acid & Lemon Grass & Suitable & Violated & $\begin{array}{l}\text { Not } \\
\text { qualified }\end{array}$ & Midstructure & $\begin{array}{l}\text { Out of } 90 \% \\
\text { cutoff }\end{array}$ \\
\hline Chlorogenic acid & Lemon Grass & Suitable & Violated & $\begin{array}{l}\text { Not } \\
\text { qualified }\end{array}$ & Midstructure & In $90 \%$ cutoff \\
\hline Orientin & Lemon Grass & Violated & Violated & Qualified & Midstructure & $\begin{array}{l}\text { Out of } 90 \% \\
\text { cutoff }\end{array}$ \\
\hline Myrcene & Lemon Grass & Suitable & Violated & $\begin{array}{l}\text { Not } \\
\text { qualified }\end{array}$ & Midstructure & $\begin{array}{l}\text { Out of } 90 \% \\
\text { cutoff }\end{array}$ \\
\hline Beta pinene & Lemon Grass & Suitable & Suitable & $\begin{array}{l}\text { Not } \\
\text { qualified }\end{array}$ & Midstructure & In $90 \%$ cutoff \\
\hline Linalool & Lemon Grass & Suitable & Suitable & $\begin{array}{l}\text { Not } \\
\text { qualified }\end{array}$ & Midstructure & $\begin{array}{l}\text { Out of } 90 \% \\
\text { cutoff }\end{array}$ \\
\hline Farnesol & Lemon Grass & Suitable & Violated & Qualified & Midstructure & $\begin{array}{l}\text { Out of } 90 \% \\
\text { cutoff }\end{array}$ \\
\hline Barneol & Lemon Grass & Suitable & Suitable & $\begin{array}{l}\text { Not } \\
\text { qualified }\end{array}$ & Midstructure & In $90 \%$ cutoff \\
\hline Caffeic acid & Lemon Grass & Suitable & Suitable & $\begin{array}{l}\text { Not } \\
\text { qualified }\end{array}$ & Midstructure & In $90 \%$ cutoff \\
\hline Alpha Tocopherols & Grape & Suitable & Violated & $\begin{array}{l}\text { Not } \\
\text { qualified }\end{array}$ & Midstructure & $\begin{array}{l}\text { Out of } 90 \% \\
\text { cutoff }\end{array}$ \\
\hline Beta carotene & Grape & Violated & Violated & $\begin{array}{l}\text { Not } \\
\text { qualified }\end{array}$ & Midstructure & $\begin{array}{l}\text { Out of } 90 \% \\
\text { cutoff }\end{array}$ \\
\hline Benzethonium & Grape & Suitable & Violated & $\begin{array}{l}\text { Not } \\
\text { qualified }\end{array}$ & Midstructure & $\begin{array}{l}\text { Out of } 90 \% \\
\text { cutoff }\end{array}$ \\
\hline Bergamottin & Grape & Suitable & Violated & Qualified & Midstructure & $\begin{array}{l}\text { Out of } 90 \% \\
\text { cutoff }\end{array}$ \\
\hline Bergapten & Grape & Suitable & Suitable & Qualified & Midstructure & In $90 \%$ cutoff \\
\hline Citric acid & Grape & Suitable & Violated & $\begin{array}{l}\text { Not } \\
\text { qualified }\end{array}$ & Midstructure & $\begin{array}{l}\text { Out of } 90 \% \\
\text { cutoff }\end{array}$ \\
\hline Azadirachtin & Grape & Violated & Violated & Qualified & Midstructure & $\begin{array}{l}\text { Out of } 90 \% \\
\text { cutoff }\end{array}$ \\
\hline Limonin & Grape & Violated & Violated & Qualified & Midstructure & $\begin{array}{l}\text { Out of } 90 \% \\
\text { cutoff }\end{array}$ \\
\hline Methyl paraben & Grape & Suitable & Suitable & $\begin{array}{l}\text { Not } \\
\text { qualified }\end{array}$ & Midstructure & In $90 \%$ cutoff \\
\hline Narangenin & Grape & Suitable & Suitable & Qualified & Midstructure & In $90 \%$ cutoff \\
\hline Narangin & Grape & Violated & Violated & $\begin{array}{l}\text { Not } \\
\text { qualified }\end{array}$ & Midstructure & $\begin{array}{l}\text { Out of } 90 \% \\
\text { cutoff }\end{array}$ \\
\hline
\end{tabular}




\begin{tabular}{|c|c|c|c|c|c|c|}
\hline Nootkatone & Grape & Suitable & Violated & Qualified & Midstructure & In $90 \%$ cutoff \\
\hline Putrescine & Grape & Suitable & Violated & $\begin{array}{l}\text { Not } \\
\text { qualified }\end{array}$ & Non-druglike & In $90 \%$ cutoff \\
\hline Resveratron & Grape & Suitable & Suitable & Qualified & Midstructure & In $90 \%$ cutoff \\
\hline Triclosan & Grape & Suitable & Violated & Qualified & Midstructure & $\begin{array}{l}\text { Out of } 90 \% \\
\text { cutoff }\end{array}$ \\
\hline
\end{tabular}

Table 2: ADME prediction of herbal compounds in plant extract using Pre-ADMET tool. ADME properties of Melantriol and $\beta$ sitosterol showed that these compounds are good lead molecules.

\begin{tabular}{|c|c|c|c|c|c|c|}
\hline $\begin{array}{l}\text { Active compound in } \\
\text { Plant extract }\end{array}$ & Source & $\begin{array}{l}\text { Human } \\
\text { Intestinal } \\
\text { Absorption }\end{array}$ & $\begin{array}{l}\text { Caco2 Cell } \\
\text { Permeability }\end{array}$ & $\begin{array}{l}\text { MDCK Cell } \\
\text { Permeability }\end{array}$ & $\begin{array}{l}\text { Skin } \\
\text { Permeability }\end{array}$ & $\begin{array}{l}\text { Blood Brain } \\
\text { Barrier } \\
\text { Penetration }\end{array}$ \\
\hline Nimbin & Neem & Well absorbed & Middle & Low & -2.894 & Middle \\
\hline Quercetin & Neem & Moderate & Low & Low & -4.433 & Middle \\
\hline Meliantriol & Neem & Well absorbed & Middle & Low & -3.095 & Middle \\
\hline Aloin & Aloe vera & Poor & Middle & Low & -4.7114 & Low \\
\hline Emodin & Aloe vera & Well absorbed & Middle & Middle & -4.29575 & Middle \\
\hline Salicyclic acid & Aloe vera & Well absorbed & Middle & Middle & -2.04714 & Middle \\
\hline Cholestrol & Aloe vera & Well absorbed & Middle & Middle & -0.64315 & High \\
\hline Campesterol & Aloe vera & Well absorbed & Middle & Low & -0.62172 & High \\
\hline Lupeol & Aloe vera & Well absorbed & Middle & Low & -1.9778 & High \\
\hline$\beta$-sitosterol & Aloe vera & Well absorbed & Middle & Low & -0.59344 & High \\
\hline Oleanolic acid & Tulsi & Well absorbed & Middle & Low & -2.354 & High \\
\hline Ursolic acid & Tulsi & Well absorbed & Middle & Low & -2.1509 & High \\
\hline Rosmarinic acid & Tulsi & Moderate & Middle & Low & -3327 & Middle \\
\hline Eugenol & Tulsi & Well absorbed & Middle & Middle & -1.3109 & High \\
\hline Carvacrol & Tulsi & Well absorbed & Middle & Middle & -1.04552 & Middle \\
\hline Linalool & Tulsi & Well absorbed & Middle & Middle & -0.895 & High \\
\hline Beta-caryophyllene & Tulsi & Well absorbed & Middle & Middle & -0.676 & High \\
\hline Methyl cinnamate & Tulsi & Well absorbed & Middle & Middle & -1.423 & Middle \\
\hline Apigenin & Tulsi & Well absorbed & Middle & Middle & -4.1457 & Middle \\
\hline Luteolin & Tulsi & Well absorbed & Middle & Low & -4.28 & Middle \\
\hline curcumin & Turmeric & $\begin{array}{l}\text { Moderately } \\
\text { absorbed }\end{array}$ & $\begin{array}{l}\text { Middle } \\
\text { permeablity }\end{array}$ & $\begin{array}{l}\text { Low } \\
\text { permeablity }\end{array}$ & -3.62686 & $\begin{array}{l}\text { Middle } \\
\text { absorption to } \\
\text { CNS }\end{array}$ \\
\hline Demethoxy curcumin & Turmeric & Well absorbed & $\begin{array}{l}\text { Middle } \\
\text { permeablity }\end{array}$ & $\begin{array}{l}\text { Middle } \\
\text { permeablity }\end{array}$ & -2.21821 & $\begin{array}{l}\text { Middle } \\
\text { absorption to } \\
\text { CNS }\end{array}$ \\
\hline Tumerone & Turmeric & Well absorbed & $\begin{array}{l}\text { Middle } \\
\text { permeablity }\end{array}$ & $\begin{array}{l}\text { Middle } \\
\text { permeablity }\end{array}$ & -0.92884 & $\begin{array}{l}\text { High absorption } \\
\text { to CNS }\end{array}$ \\
\hline Diaryl heptanoid & Turmeric & Well absorbed & $\begin{array}{l}\text { Middle } \\
\text { permeablity }\end{array}$ & $\begin{array}{l}\text { Low } \\
\text { permeablity }\end{array}$ & -2.25168 & $\begin{array}{l}\text { Middle } \\
\text { absorption to } \\
\text { CNS }\end{array}$ \\
\hline Allicin & Garlic & Well absorbed & $\begin{array}{l}\text { Middle } \\
\text { permeablity }\end{array}$ & $\begin{array}{l}\text { Middle } \\
\text { permeablity }\end{array}$ & -1.36911 & $\begin{array}{l}\text { Middle } \\
\text { absorption to } \\
\text { CNS }\end{array}$ \\
\hline Diallyl sulphide & Garlic & Well absorbed & $\begin{array}{l}\text { Middle } \\
\text { permeablity }\end{array}$ & $\begin{array}{l}\text { Low } \\
\text { permeablity }\end{array}$ & -1.17034 & $\begin{array}{l}\text { Middle } \\
\text { absorption to } \\
\text { CNS }\end{array}$ \\
\hline Diallyl disulphide & Garlic & Well absorbed & $\begin{array}{l}\text { Middle } \\
\text { permeablity }\end{array}$ & $\begin{array}{l}\text { Low } \\
\text { permeablity }\end{array}$ & -1.08723 & $\begin{array}{l}\text { Middle } \\
\text { absorption to } \\
\text { CNS }\end{array}$ \\
\hline Brevifolin & Pomogranate & Well absorbed & $\begin{array}{l}\text { Middle } \\
\text { permeablity }\end{array}$ & $\begin{array}{l}\text { Middle } \\
\text { permeablity }\end{array}$ & -2.39945 & $\begin{array}{l}\text { Middle } \\
\text { absorption to } \\
\text { CNS }\end{array}$ \\
\hline Ellagic acid & Pomogranate & Well absorbed & $\begin{array}{l}\text { Middle } \\
\text { permeablity }\end{array}$ & $\begin{array}{l}\text { Low } \\
\text { permeablity }\end{array}$ & -1.15024 & $\begin{array}{l}\text { Middle } \\
\text { absorption to } \\
\text { CNS }\end{array}$ \\
\hline Gallic acid & Pomogranate & $\begin{array}{l}\text { Moderately } \\
\text { absorbed }\end{array}$ & $\begin{array}{l}\text { Middle } \\
\text { permeablity }\end{array}$ & $\begin{array}{l}\text { Low } \\
\text { permeablity }\end{array}$ & -3.62686 & $\begin{array}{l}\text { Middle } \\
\text { absorption to } \\
\text { CNS }\end{array}$ \\
\hline $\begin{array}{l}\text { Epigallacatechin } \\
\text { gallate }\end{array}$ & Tea & $\begin{array}{l}\text { Moderately } \\
\text { absorbed }\end{array}$ & $\begin{array}{l}\text { Middle } \\
\text { permeablity }\end{array}$ & $\begin{array}{l}\text { Low } \\
\text { permeablity }\end{array}$ & -3.9954 & $\begin{array}{l}\text { Low absorption } \\
\text { to CNS }\end{array}$ \\
\hline Corilagin & Tea & Poorly absorbed & $\begin{array}{l}\text { Middle } \\
\text { permeablity }\end{array}$ & $\begin{array}{l}\text { Low } \\
\text { permeablity }\end{array}$ & -4.32617 & $\begin{array}{l}\text { Low absorption } \\
\text { to CNS }\end{array}$ \\
\hline Thymol & Clove & Well absorbed & Middle & Middle & -1.06531 & High \\
\hline
\end{tabular}




\begin{tabular}{|c|c|c|c|c|c|c|}
\hline Alpha-pinene & Eucalyptus & Well absorbed & Middle & Middle & -1.44636 & High \\
\hline Benzyl benzoate & Eucalyptus & Well absorbed & Middle & Low & -2.03706 & High \\
\hline Geranial & Eucalyptus & Well absorbed & Middle & Middle & -0.96121 & High \\
\hline Limonene & Eucalyptus & Well absorbed & Middle & Middle & -0.8341 & High \\
\hline Ethyl cinnamate & Eucalyptus & Well absorbed & Middle & Middle & -1.33427 & Middle \\
\hline Terpinen & Eucalyptus & Well absorbed & Middle & Middle & -1.30527 & High \\
\hline Thujene & Eucalyptus & Well absorbed & Middle & Middle & -1.43448 & High \\
\hline Cinnamaldehyde & Cinnamon & Well absorbed & Middle & Middle & -1.3358 & Middle \\
\hline Cinnamyl alcohol & Cinnamon & Well absorbed & Middle & Middle & -1.38467 & Middle \\
\hline Cinnamyl acetate & Cinnamon & Well absorbed & Middle & Middle & -1.36474 & Middle \\
\hline Ferulic acid & Guava & Well absorbed & Middle & Middle & -1.872 & High \\
\hline Ascorbic acid & Guava & $\begin{array}{l}\text { Moderately } \\
\text { absorbed }\end{array}$ & Low & Low & -5.14959 & Middle \\
\hline Gallic acid & Guava & $\begin{array}{l}\text { Moderately } \\
\text { absorbed }\end{array}$ & Middle & Low & -3.62686 & High \\
\hline Casuarinin & Guava & Poorly absorbed & Middle & Low & -3.1221 & Middle \\
\hline Cyanidin & Guava & Well absorbed & Low & Middle & -4.13468 & High \\
\hline Geraniol & Lemon Grass & Well absorbed & Middle & Middle & -1.05921 & High \\
\hline Citral & Lemon Grass & Well absorbed & Middle & Middle & -0.9612 & High \\
\hline Geranic acid & Lemon Grass & Well absorbed & Middle & Middle & -1.07 & High \\
\hline Chlorogenic acid & Lemon Grass & $\begin{array}{l}\text { Moderately } \\
\text { absorbed }\end{array}$ & Middle & Low & -3.89403 & Middle \\
\hline Orientin & Lemon Grass & Poorly absorbed & Low & Low & -4.684 & Middle \\
\hline Myrcene & Lemon Grass & Well absorbed & Middle & Middle & -0.6329 & High \\
\hline Beta pinene & Lemon Grass & Well absorbed & Middle & Middle & -1.3583 & High \\
\hline Linalool & Lemon Grass & Well absorbed & Middle & Middle & -0.8956 & High \\
\hline Farnesol & Lemon Grass & Well absorbed & Middle & Middle & -0.6274 & High \\
\hline Barneol & Lemon Grass & Well absorbed & Middle & Middle & -1.88173 & High \\
\hline Caffeic acid & Lemon Grass & Well absorbed & Middle & Middle & -2.6699 & High \\
\hline Alpha Tocopherols & Grape & Well absorbed & Middle & Middle & -0.51599 & High \\
\hline Beta carotene & Grape & Well absorbed & Middle & Middle & -0.60917 & High \\
\hline Benzethonium & Grape & Well absorbed & Middle & Low & -0.8867 & Middle \\
\hline Bergamottin & Grape & Well absorbed & Middle & Low & -2.4988 & High \\
\hline Bergapten & Grape & well absorbed & Middle & Middle & -3.7077 & High \\
\hline Citric acid & Grape & Poorly absorbed & Middle & Low & -3.94504 & Middle \\
\hline Azadirachtin & Grape & $\begin{array}{l}\text { Moderately } \\
\text { absorbed }\end{array}$ & Middle & Low & -4.67787 & Middle \\
\hline Limonin & Grape & Well absorbed & Middle & Low & -3.733 & Middle \\
\hline Methyl paraben & Grape & Well absorbed & Middle & Middle & -2.009 & High \\
\hline Narangenin & Grape & Well absorbed & Middle & Middle & -4.1802 & High \\
\hline Narangin & Grape & Poorly absorbed & Middle & Low & -4.54 & High \\
\hline Nootkatone & Grape & Well absorbed & Middle & Middle & -0.899 & High \\
\hline Putrescine & Grape & Well absorbed & Middle & Low & -4.091 & Middle \\
\hline Resveratron & Grape & Well absorbed & Middle & Middle & -3.1525 & High \\
\hline Triclosan & Grape & Well absorbed & Middle & Middle & -2.2848 & High \\
\hline
\end{tabular}

Table 3: Toxicity prediction of selected herbal compounds by Pre-ADMET tool. The toxicity testing have given satisfactory results for both Melantriol and $\beta$-sitosterol.

\begin{tabular}{|c|c|c|c|c|c|c|c|c|c|c|}
\hline \multirow{3}{*}{$\begin{array}{l}\text { Active compound in plant } \\
\text { extract }\end{array}$} & \multirow{3}{*}{ Source } & \multicolumn{7}{|c|}{ AMES Test } & \multirow{2}{*}{\multicolumn{2}{|c|}{ Carcinogenicity }} \\
\hline & & $\mathrm{TA}_{100}$ & $\mathrm{TA}_{100}$ & $\mathrm{TA}_{1535}$ & $\mathrm{TA}_{1535}$ & $\mathrm{TA}_{98}$ & $\mathrm{TA}_{98}$ & Result & & \\
\hline & & $+\mathrm{s} 9$ & -s9 & $+\mathrm{s} 9$ & $-s 9$ & $+\mathrm{s} 9$ & $-\mathrm{s} 9$ & & Mouse & Rat \\
\hline Quercetin & Neem & - & + & - & - & - & + & Mutagen & - & + \\
\hline Meliantriol & Neem & - & - & - & - & - & - & $\begin{array}{l}\text { Non } \\
\text { mutagen }\end{array}$ & - & - \\
\hline Aloin & Neem & - & - & - & - & + & - & Mutagen & - & - \\
\hline Emodin & Aloe vera & - & + & - & - & + & + & Mutagen & - & + \\
\hline Salicyclic acid & Aloe vera & + & + & + & - & + & - & Mutagen & - & - \\
\hline Cholestrol & Aloe vera & - & - & - & - & - & - & $\begin{array}{l}\text { Non } \\
\text { mutagen }\end{array}$ & + & - \\
\hline Campesterol & Aloe vera & - & - & - & - & - & - & $\begin{array}{l}\text { Non } \\
\text { mutagen }\end{array}$ & + & - \\
\hline Lupeol & Aloe vera & - & - & - & - & - & + & Mutagen & - & + \\
\hline$\beta$-sitosterol & Aloe vera & - & - & - & - & - & - & $\begin{array}{l}\text { Non } \\
\text { mutagen }\end{array}$ & - & - \\
\hline Oleanolic acid & Aloe vera & - & - & - & - & - & - & Non & + & + \\
\hline
\end{tabular}




\begin{tabular}{|c|c|c|c|c|c|c|c|c|c|c|}
\hline Ursolic acid & Tulsi & - & - & - & - & - & - & $\begin{array}{l}\text { mutagen } \\
\text { Non } \\
\text { mutagen }\end{array}$ & + & + \\
\hline Rosmarinic acid & Tulsi & - & - & - & - & - & - & $\begin{array}{l}\text { Non } \\
\text { mutagen }\end{array}$ & - & + \\
\hline Eugenol & Tulsi & + & + & + & - & + & + & Mutagen & + & + \\
\hline Carvacrol & Tulsi & + & - & + & - & + & + & Mutagen & - & - \\
\hline Linalool & Tulsi & + & - & + & - & - & - & Mutagen & - & - \\
\hline Beta-caryophyllene & Tulsi & - & - & - & - & - & + & Mutagen & - & + \\
\hline Methyl cinnamate & Tulsi & + & + & - & - & + & - & Mutagen & - & - \\
\hline Apigenin & Tulsi & - & + & - & - & - & + & Mutagen & - & + \\
\hline Luteolin & Tulsi & - & + & - & - & - & $=$ & Mutagen & - & + \\
\hline curcumin & Tulsi & - & + & + & - & - & - & Mutagen & - & + \\
\hline Demethoxy curcumin & Turmeric & - & - & - & - & - & - & $\begin{array}{l}\text { Non } \\
\text { mutagen }\end{array}$ & - & + \\
\hline Tumerone & Turmeric & - & - & - & - & + & - & Mutagen & + & + \\
\hline Diaryl heptanoid & Turmeric & - & - & - & - & - & - & $\begin{array}{l}\text { Non } \\
\text { mutagen }\end{array}$ & - & - \\
\hline Allicin & Turmeric & - & - & + & - & - & - & $\begin{array}{l}\text { Non } \\
\text { mutagen }\end{array}$ & + & - \\
\hline Diallyl sulphide & Garlic & - & - & - & - & - & - & $\begin{array}{l}\text { Non } \\
\text { mutagen }\end{array}$ & + & + \\
\hline Diallyl disulphide & Garlic & - & - & - & - & - & - & $\begin{array}{l}\text { Non } \\
\text { mutagen }\end{array}$ & + & + \\
\hline Brevifolin & Garlic & - & + & - & - & + & - & Mutagen & - & + \\
\hline Ellagic acid & Pomogranate & - & - & - & - & - & - & $\begin{array}{l}\text { Non } \\
\text { mutagen }\end{array}$ & + & + \\
\hline Gallic acid & Pomogranate & - & + & + & - & - & - & Mutagen & - & + \\
\hline Punicafolin & Pomogranate & & & & & & & & & \\
\hline Epigallacatechin gallate & Tea & - & - & - & - & - & - & $\begin{array}{l}\text { Non } \\
\text { mutagen }\end{array}$ & - & + \\
\hline Corilagin & Tea & - & - & - & - & - & - & $\begin{array}{l}\text { Non } \\
\text { mutagen }\end{array}$ & - & - \\
\hline Thymol & Clove & + & + & + & - & + & + & Mutagen & - & - \\
\hline Alpha-pinene & Eucalyptus & + & - & - & - & - & - & Mutagen & - & + \\
\hline Benzyl benzoate & Eucalyptus & + & + & - & - & + & 冫 & Mutagen & - & - \\
\hline Geranial & Eucalyptus & - & + & + & - & + & - & Mutagen & - & + \\
\hline Limonene & Eucalyptus & - & - & - & - & + & + & Mutagen & - & + \\
\hline Ethyl cinnamate & Eucalyptus & + & + & - & - & + & - & Mutagen & - & - \\
\hline Terpinen & Eucalyptus & - & - & + & - & - & + & Mutagen & + & - \\
\hline Thujene & Eucalyptus & + & - & - & - & + & - & Mutagen & + & + \\
\hline Cinnamaldehyde & Cinnamon & + & - & - & - & + & - & Mutagen & - & - \\
\hline Cinnamyl alcohol & Cinnamon & + & - & - & - & + & - & Mutagen & - & - \\
\hline Cinnamyl acetate & Cinnamon & + & - & - & - & + & - & Mutagen & - & - \\
\hline Ferulic acid & Guava & - & + & + & - & + & - & Mutagen & - & + \\
\hline Ascorbic acid & Guava & - & + & + & - & + & - & Mutagen & - & - \\
\hline Gallic acid & Guava & - & + & + & - & - & - & Mutagen & - & + \\
\hline Casuarinin & Guava & - & - & - & - & - & - & $\begin{array}{l}\text { Non } \\
\text { mutagen }\end{array}$ & - & + \\
\hline Cyanidin & Guava & - & + & - & - & $\begin{array}{l}\text { out of } \\
\text { range }\end{array}$ & + & Mutagen & - & - \\
\hline Geraniol & Lemon Grass & - & + & - & - & + & - & Mutagen & + & - \\
\hline Citral & Lemon Grass & - & + & + & - & + & - & Mutagen & - & + \\
\hline Geranic acid & Lemon Grass & - & - & + & - & + & - & Mutagen & + & + \\
\hline Chlorogenic acid & Lemon Grass & - & - & - & - & - & - & $\begin{array}{l}\text { Non } \\
\text { mutagen }\end{array}$ & - & - \\
\hline Orientin & Lemon Grass & - & - & - & - & - & - & $\begin{array}{l}\text { Non } \\
\text { mutagen }\end{array}$ & - & - \\
\hline Myrcene & Lemon Grass & - & - & - & - & + & - & Mutagen & - & + \\
\hline Beta pinene & Lemon Grass & + & - & - & - & - & + & Mutagen & - & + \\
\hline Linalool & Lemon Grass & + & - & - & - & + & - & Mutagen & - & - \\
\hline Farnesol & Lemon Grass & - & - & - & - & - & - & $\begin{array}{l}\text { Non } \\
\text { mutagen }\end{array}$ & + & - \\
\hline Barneol & Lemon Grass & - & - & + & - & - & - & Mutagen & - & + \\
\hline Caffeic acid & Lemon Grass & - & + & + & - & + & - & Mutagen & - & + \\
\hline Alpha Tocopherols & Grape & - & - & - & - & - & - & Non & - & - \\
\hline
\end{tabular}




\begin{tabular}{|c|c|c|c|c|c|c|c|c|c|c|}
\hline Beta carotene & Grape & - & - & - & - & - & - & $\begin{array}{l}\text { mutagen } \\
\text { Non } \\
\text { mutagen }\end{array}$ & + & + \\
\hline Benzethonium & Grape & - & - & - & - & + & - & Mutagen & - & - \\
\hline Bergamottin & Grape & - & + & - & - & + & + & Mutagen & + & - \\
\hline Bergapten & Grape & + & + & + & - & + & + & Mutagen & - & + \\
\hline Citric acid & Grape & - & - & + & - & - & - & Mutagen & - & + \\
\hline Azadirachtin & Grape & - & - & - & - & - & - & $\begin{array}{l}\text { Non } \\
\text { mutagen }\end{array}$ & + & + \\
\hline Limonin & Grape & - & - & - & - & - & - & $\begin{array}{l}\text { Non } \\
\text { mutagen }\end{array}$ & - & + \\
\hline Methyl paraben & Grape & + & + & + & - & + & - & Mutagen & - & - \\
\hline Narangenin & Grape & + & + & - & - & - & + & Mutagen & - & + \\
\hline Narangin & Grape & - & - & - & - & - & - & $\begin{array}{l}\text { Non } \\
\text { mutagen }\end{array}$ & - & - \\
\hline Nootkatone & Grape & - & - & + & - & - & + & Mutagen & - & + \\
\hline Putrescine & Grape & - & - & - & - & - & - & $\begin{array}{l}\text { Non } \\
\text { mutagen }\end{array}$ & + & + \\
\hline Resveratron & Grape & - & - & - & - & - & + & Mutagen & - & - \\
\hline Triclosan & Grape & - & - & - & - & - & + & Mutagen & + & - \\
\hline
\end{tabular}

Table 4: The binding energies $(\mathrm{kcal} / \mathrm{mol})$ of various plant derived compounds and antibiotics with PBP2A and PVL toxin after molecular docking. Melantriol and $\beta$-sitosterol have showed better binding energies. The table also indicating that herbal based compounds have better binding affinities towards PBP2A and PVL toxin of MRSA than antibiotics

\begin{tabular}{|c|c|c|c|}
\hline $\begin{array}{l}\text { Compound } \\
\text { ID }\end{array}$ & $\begin{array}{l}\text { Antibiotics/ Herbal active } \\
\text { compound }\end{array}$ & $\begin{array}{l}\text { Binding Energy Value With PBP2A } \\
(\mathrm{kcal} / \mathrm{mol})\end{array}$ & $\begin{array}{l}\text { Binding Energy Value With } \\
\text { PVL }\end{array}$ \\
\hline DB00512 & Vancomycin & -8.91 & -5.81 \\
\hline CID:6024 & Cephalothin & -5.91 & -3.72 \\
\hline CID:6604200 & Nitrofurantoin & -5.41 & -3.69 \\
\hline CID:3476 & Gentamicin & -5.26 & -4.36 \\
\hline CID:37768 & Amikacin & -5.13 & -4.13 \\
\hline CID:298 & Chloramphenicol & -4.49 & -2.84 \\
\hline CID:149096 & Levofloxacin & -4.35 & -3.76 \\
\hline C16783 & Meliantriol & -6.02 & -8.94 \\
\hline CID:108058 & Nimbin & -5.84 & -3.42 \\
\hline CID:5280343 & Quercetin & -5.02 & -5.11 \\
\hline CID:222284 & $\beta$-sitosterol & -7.40 & -6.34 \\
\hline CID:5997 & Cholestrol & -7.09 & -6.70 \\
\hline CID:3220 & Emodin & -6.49 & -5.15 \\
\hline CID:173183 & Campesterol & -6.38 & -5.71 \\
\hline C08628 & Lupeol & -6.24 & -5.65 \\
\hline C10305 & Aloin & -4.96 & -6.08 \\
\hline CID:338 & Salicyclic acid & -4.71 & -4.42 \\
\hline CID: 73568 & Corilagin & -6.34 & -5.85 \\
\hline CID:65064 & Epigallacatechin gallate & -5.56 & -3.60 \\
\hline CID:445858 & Ferulic acid & -4.55 & -5.84 \\
\hline CID:128861 & Cyanidin & -4.10 & -5.09 \\
\hline CID:5785 & Ascorbic acid & -4.05 & -3.94 \\
\hline CID:138517 & Casuarinin & -5.18 & -4.70 \\
\hline CID:445858 & Ferulic acid & -4.55 & -5.84 \\
\hline CID:128861 & Cyanidin & -4.10 & -5.09 \\
\hline CID:5785 & Ascorbic acid & -4.05 & -3.94 \\
\hline CID:5281855 & Ellagic acid & -5.45 & -6.31 \\
\hline CID:9838995 & Brevifolin & -5.16 & -6.37 \\
\hline CID:370 & Gallic acid & -4.10 & -2.61 \\
\hline CID:65036 & Allcin & -6.52 & -3.67 \\
\hline CID:16590 & Diallyl sulphide & -2.79 & -3.41 \\
\hline CID:11617 & Diallyl disulphide & -2.61 & -4.65 \\
\hline CID:4445319 & Cinnamyl acetate & -4.52 & -4.67 \\
\hline CID:21105870 & Cinnamyl alcohol & -4.21 & -5.20 \\
\hline CID:637511 & Cinnamaldehyde & -3.60 & -3.89 \\
\hline CID:21105998 & Thymol & -4.13 & -4.57 \\
\hline CID:573 & Beta-carotene & -6.44 & -6.46 \\
\hline CID:442428 & Narangin & -5.87 & -5.76 \\
\hline CID:932 & Narangenin & -5.67 & -6.43 \\
\hline CID:1268142 & Nootkatone & -5.42 & -5.46 \\
\hline
\end{tabular}




\begin{tabular}{|c|c|c|c|}
\hline CID:5564 & Triclosan & -5.36 & -4.83 \\
\hline CID:1045 & Putrescine & -5.27 & -4.53 \\
\hline CID:2355 & Bergapten & -5.05 & -4.36 \\
\hline CID:5471349 & Bergamottin & -4.99 & -4.91 \\
\hline CID:14985 & Alpha-tocopherols & -4.96 & -4.36 \\
\hline CID:392875 & Resveratron & -4.86 & -4.38 \\
\hline CID:5281303 & Azadirachtin & -4.43 & -4.45 \\
\hline CID:311 & Ciric acid & -4.25 & -4.67 \\
\hline CID:7456 & Methyl paraben & -3.65 & -4.89 \\
\hline CID:6507 & Limonin & -3.41 & -4.53 \\
\hline CID:8478 & Benzethonium chloride & -2.98 & -4.01 \\
\hline CID:2345 & Benzyl benzoate & -4.86 & -4.76 \\
\hline CID:22311 & Limonene & -4.47 & -4.43 \\
\hline CID:6380311 & Geranial & -4.37 & -3.89 \\
\hline CID:440968 & Alpha-pinene & -4.35 & -4.86 \\
\hline CID:637758 & Ethyl cinnamate & -4.27 & -4.35 \\
\hline CID:420384 & Thujene & -3.98 & -4.02 \\
\hline CID:64945 & Ursolic acid & -6.90 & -4.48 \\
\hline CID:10494 & Oleanolic acid & -6.30 & -5.47 \\
\hline CID:5280445 & Luteolin & -5.68 & -5.47 \\
\hline CID:5280443 & Apigenin & -5.54 & -5.87 \\
\hline CID:5281515 & Beta-caryophyllene & -5.48 & -5.52 \\
\hline CID:637520 & Methyl cinnamate & -4.03 & -5.08 \\
\hline CID:3314 & Eugenol & -3.90 & -4.86 \\
\hline CID:10364 & Carvacrol & -3.86 & -3.78 \\
\hline CID:5315615 & Rosmarinic acid & -3.79 & -4.27 \\
\hline CID:6549 & Linalool & -3.49 & -4.38 \\
\hline CID:1405788 & Chlorogenic acid & -5.27 & -4.38 \\
\hline CID:689043 & Caffeic acid & -5.21 & -4.89 \\
\hline CID:5281675 & Orientin & -4.88 & -5.47 \\
\hline CID:14896 & Beta-pinene & -4.12 & -5.23 \\
\hline CID:31253 & Myrcene & -4.10 & -5.47 \\
\hline CID:5275520 & Geranic acid & -4.10 & -4.18 \\
\hline CID:6552009 & Barneol & -3.93 & -4.64 \\
\hline CID:13849989 & Geraniol & -3.88 & -4.89 \\
\hline CID:638011 & Citrial & -3.77 & -4.23 \\
\hline CID:3327 & Farnesol & -3.66 & -4.46 \\
\hline
\end{tabular}

Table 5: Antibiotic susceptibility analysis of MRSA. The study revealed that MRSA has emerged as superbug because it resistant to multiple antibiotics. Vancomycin is the best antibiotics available against MRSA infection. But recent report revealed that the organism developed resistant against Vancomycin (VRSA)

\begin{tabular}{|c|c|c|c|c|}
\hline Antibiotic & Symbol & Concentration (mcg) & Diameter of zone of inhibition(mm) & Susceptibility pattern \\
\hline Moxifloxacin & $\mathrm{MO}$ & 5 & 22 & Intermediate \\
\hline Cefatoxime & CTX & 30 & 14 & Resistant \\
\hline Rifampicin & RIF & 5 & Nil & Resistant \\
\hline Oxacillin & OX & 1 & Nil & Resistant \\
\hline Co-Trimoxazole & COT & 25 & Nil & Resistant \\
\hline Ciprofloxcin & $\mathrm{CIP}$ & 5 & 16 & Intermediate \\
\hline Ceftazidime & CAZ & 30 & 10 & Resistant \\
\hline Nalidixic acid & NA & 30 & 9 & Resistant \\
\hline Gentamicin & GEN & 10 & 15 & Sensitive \\
\hline Tetracycline & $\mathrm{TE}$ & 30 & 12 & Resistant \\
\hline Levofloxacin & $\mathrm{LE}$ & 5 & 20 & Sensitive \\
\hline Nitrofurantoin & NIT & 300 & 19 & Sensitive \\
\hline Amikacin & AK & 30 & 18 & Sensitive \\
\hline Streptomycin & S & 10 & 8 & Resistant \\
\hline Chloramphenicol & $\mathrm{C}$ & 30 & 26 & Sensitive \\
\hline Erythromycin & $\mathrm{E}$ & 15 & Nil & Resistant \\
\hline Ampicillin & AMP & 10 & 11 & Resistant \\
\hline Vancomycin & VA & 30 & 15 & Sensitive \\
\hline Cephalothin & CEP & 30 & 23 & Sensitive \\
\hline Norfloxacin & NX & 10 & 8 & Resistant \\
\hline Methicillin & MET & 5 & Nil & Resistant \\
\hline
\end{tabular}

